\title{
НОВЫЕ КНИГИ
}

\section{К ВОПРОСУ ОБ ОСЕТИНО-БАЛКАРО-КАРАЧАЕВСКИХ НАРТОВСКИХ ПАРАЛЛЕЛЯХ}

\begin{abstract}
А.Л. Чибиров
Деликатность и подчеркнутое взаимоуважение друг к другу были основой поведенческого этикета кавказиев. Кавказ вместил в себя десятки народов с уникальной культурой, особой индивидуальностью и собственной картиной мира. Надо обладать совершенной интуицией, тактом и соответствующим образованием для того, чтобы разобраться в особенностях менталитета того или иного народа, проживающего в этом ареале. Кавказ всегда был интересен исследователям разнообразием культур. Существуют общекавказские темьи, которые не теряют своей актуальности в зависимости от общественно-политической конъюнктуры. Одной из таких тем является Нартиада. Осетино-карачаево-балкарские нартовские параллели, озвученные в названии статьи, рассматриваются на примере монографии известного балкарского ученого, доктора филологических наук, фольклориста и тюрколога Хамида Хашимовича Малкондуева. Книга называется «Карачаево-балкарский нартский эпос. Теория. Историзм. Самобытность». Исследователям свойственно рассматривать работы коллег в критическом русле. Автор же стремится найти в этой работе точки соприкосновения, идеи, которые не вносят семена раздора и непонимания, но объединяют народы на общекавказском пространстве, на котором суждено жить вместе, в дружбе и согласии. Автор анализирует монографию Малкондуева с позиции историка. Подчеркивает объективность и принципиальность ученого, который в поисках истины не позволяет себе поддаться сиюминутным веяниям не всегда верного общественного мнения. Как известно, мощным толчком для активного изучения национальных версий Нартиады, послужила опубликованная в 1945 г. работа В. И. Абаева «Нартовский эпос», в которой он отмечал интернациональный характер эпоса. Вместе с тем, Абаев утверждал, что основу, стержень нартовских сказаний составляет аланский эпический цикл, привнесенный на Кавказ предками современных осетин. Эти слова выдающего ученого служат лейтмотивом представленной статьи.
\end{abstract}

Ключевые слова: Нарты, Урузмаг, Сатана, осетины, карачаевцы, балкариы, В. И. Абаев.

Delicacy and mutual respect were always the basis of the behavioural etiquette of the Caucasians. The Caucasus is home for many peoples with unique culture, distinctive individuality and their own worldview. To figure peculiarities of mentality of the peoples, that reside in this region, one need to have perfect intuition, tact and appropriate education. Researches have always been fascinated by the diversity of the Caucasus. There is a certain number of common Caucasian issues that remain relevant notwithstanding the socio-political conjuncture. One of such issues is the Nartiada. The Ossetian-Balkar-Karachay Nart parallels stated in the title of the presented article are given in Khamid Khashimovich Malkonduev's monograph, who is a Balkarian scientist, Ph.D. in Linguistics, a folklorist and a turcologist. The title of his book is «Karachay-Balkar Nart Sagas. Theory. Historicism. Originality». Researchers usually tend to review their colleagues' works in a critical way. We will try to find in this work common ground and ideas that can unite us in the all-Caucasian space, but not to sow the seeds of division or incomprehension, since we are meant to live together here, in the Caucasus, in friendship and harmony. The monograph is reviewed from the point of view 
of a professional historian, not a folklorist. The author of the monograph must be credited for his objectivity and unbiased attitudes, which he maintains in spite of the pressures and volatility of the public opinion. It is common knowledge, that V. I. Abaev's work published in 1945 «The Narts' Epos», in which he stated the international character of the epos, instigated active studying of the national versions of Nartiada. At the same time Abaev asserted, that the Alania epic cycle introduced to the Caucasus by the ancestors of the present-day Ossetians constitute the core of the Narts' sagas». These words serve as a keynote of the present article.

Keywords: Narts, Uruzmag, Satana, Ossetians, Karachays, Balkars, Abaev.

Перифраз известной поговорки, адаптированной под кавказские реалии вполне может звучать следующим образом: Кавказ - дело тонкое. И действительно, маленький Кавказ способен вместить в себя десятки народов с уникальной культурой, особой индивидуальностью и собственной картиной мира. Надо обладать совершенной интуицией, тактом и соответствующим образованием для того, чтобы разобраться в особенностях менталитета того или иного народа, проживающего в этом ареале. Кавказ всегда был интересен исследователям разнообразием культур. Однако существуют общекавказские темы, которые не теряют своей актуальности в зависимости от общественно-политической конъюнктуры. Одной из таких тем, безусловно, является Нартиада.

Осетино-карачаево-балкарские нартовские параллели, озвученные в названии моей статьи, я хотел бы продемонстрировать на примере монографии известного балкарского ученого, доктора филологических наук, фольклориста и тюрколога Хамида Хашимовича Малкондуева. Книга называется «Карачаево-балкарский нартский эпос. Теория. Историзм. Самобытность» [1]. Исследователям свойственно рассматривать работы коллег в критическом русле. Мы же постараемся найти в этой работе точки соприкосновения, идеи, которые объединяют нас на общекавказском пространстве, но никак не вносят семе- на раздора и непонимания, ибо нам всем суждено жить здесь, на Кавказе, вместе в дружбе и согласии.

Теперь что касается непосредственно представляемой монографии. Не секрет, что мощным толчком для активного изучения национальных версий Нартиады, послужила опубликованная в 1945 г. работа В.И. Абаева «Нартовский эпос». Говоря об истоках Нартиады, он писал: «Перед нами, таким образом, весьма редкий, пожалуй, единственный случай эпоса, не связанного какими-либо определенными национальными рамками, и имеющего в масштабе Северного Кавказа, ясно выраженный интернациональный характер. Существенно при этом отметить, что народы, донесшие до нас нартовский эпос, по языку и происхождению имеют между собой мало общего и относятся к трем различным этническим группам: осетины - к иранской, балкарцы и карачаевцы - к турецкой, кабардинцы, ингуши, чеченцы - к яфетической. При всех этих условиях «интернациональный характер сказаний о нартах не представляется возможным объяснить путем возведения всего эпоса к какому-то общему для всех этих народов первоисточнику. ... «Интернационализм» нашего эпоса... возник как результат позднейших интенсивных межплеменных связей и влияний, формировавших сходную во многих чертах культуру северокавказских народов. И если каждый из перечисленных выше 
горских народов и внес в эпос некоторые свои национальные мотивы и сюжеты - основу, стержень нартовских сказаний составляет аланский эпический цикл, привнесенный на Кавказ предками нынешних осетин» $[2,8]$. Эти слова могут служить лейтмотивом представленной статьи.

Я не являюсь профессиональным фольклористом, поэтому позволил себе взглянуть на монографию уважаемого Хамида Хашимовича с точки зрения историка, тем более что одна из важнейших глав книги так и называется: «Историзм и генетические истоки и традиции карачаево-балкарского нартского эпоса». Несомненно, что автор, многоопытный исследователь-фольклорист, является достаточно объективным и принципиальным ученым, который в поисках истины не позволяет себе поддаться сиюминутным веяниям не всегда верного общественного мнения. Отметим, что Х.Х. Малкондуев стоит на верных научных позициях в вопросах этногенеза балкарцев и карачаевцев, и не подвергает ревизии выводы, к которым пришли участники состоявшейся в Нальчике в 1959 г. Всесоюзной сессии по этногенезу балкарцев и карачаевцев. Он считает, что симбиоз аланских и тюркских племен еще в древности породил этническую основу карачаево-балкарской народности [1, 10]. В другом месте своей монографии он еще раз подчеркивает тот факт, что карачаево-балкарская народность произошла «в результате смешения северокавказских племен с ираноязычными и тюркоязычными племенами, из которых наибольшее значение в этом процессе имели, видимо черные булгары и, в особенности, одно из западно-кыпчакских племен» $[1,44,310]$.
Малкондуев убежден, что карачаевцы и балкарцы сформировались на местной субстратной основе, признает весомую роль алан в формировании карачаево-балкарского народа [1, 114], убедительно говорит о том, что новая народность карачаево-балкарцы, их этническая основа сформировались на Северном Кавказе из симбиоза аланских и тюркских племен. Хамид Хашимович справедливо осуждает «позднейших сказителей-модернизаторов», как их называл В.И. Абаев, авторов сомнительных публикаций с претензией на научность $[1,6]$. Нельзя не согласиться с автором, когда он пишет, что «если в 1970-1980-е гг. можно было еще встретить живых носителей эпоса, то в настоящее время их просто нет» [1, 97]. Потому и считает он весьма сомнительным научную значимость тех сказаний, которые в некоторых местах Кавказа псевдоисследователи продолжают и поныне собирать, и записывать.

В первой главе своей монографии автор дает довольно подробный и критический анализ литературы по карачаево-балкарским нартовским сказаниям, делая упор на издания последних лет. Из вышедших за последнюю четверть века трудов по карачаево-балкарскому нартовскому эпосу наиболее весомыми автор справедливо считает монографическое исследование А.З. Холаева (1974) и вступительную статью Т. М. Хаджиевой к академическому изданию Нарты (1994). Этим читатель получает нужную информацию о современном состоянии нартоведения у указанных народов, что позволяет глубже вникнуть в постановку вопросов.

Подвергнув тщательному анализу работу Хаджиевой посвященную нартовскому эпосу, и дав ей высокую оцен- 
ку как ученому, Малкондуев вместе с тем считает ошибкой использование ею термина «аланы» как этническое самоназвание карачаево-балкарцев и еще раз, как бы напоминая своим соотечественникам, пишет: «Слово «алан» в карачаево-балкарском языке означает форму - обращение друг к другу» $[1,29]$. В другом месте книги Хамид Хашимович выразил свое отношение к тем коллегам, чью точку зрения по нартовскому эпосу он не разделяет. Малкондуев пишет: «Не прошедшие научной апробации издания по карачаево-балкарскому нартскому эпосу, уровень исследования, а порою и выводы которых представляются сомнительными и довольно спорными, нами в данной работе не рассматриваются» [1, 5]. Мужественный поступок. В действительности, в книге отсутствуют ссылки на И. Мизиева, А. Байрамкулова, нет упоминания и о недавно изданном фолианте о нартовском эпосе карачаевцев и балкарцев весьма одиозного автора М.Джуртубаева. Научная принципиальность Малкондуева проявляется и тогда, когда он анализирует ранее опубликованную книгу Джуртубаева. Он выражает свое несогласие с его историческими выводами, не разделяет его мнение, согласно которому карачаево-балкарский эпос - это цельное и завершенное произведение [1, 30]. Малкондуев обоснованно критикует своих коллег, считает несерьезными попытки доказать, будто имена главных персонажей карачаево-балкарского эпоса Ерюзмек, Сатаней, Сосрук, Батыраз являются порождением карачаево-балкарской устной словесной культуры без веских на то оснований. Но и это не все. Мы солидарны с автором и в том, что этническое родство между карачаевцами, балкарцами и осетинами, носит весь- ма древний характер, и складывалось веками, что наглядно выражается в такой важной сфере как устное народное творчество. Малкондуев несомненно прав, когда пишет, что «указанная особенность этнической истории наложила свой отпечаток на все структурные компоненты материальной и духовной культуры народа, представляющей сложное переплетение степных кочевнических традиций с древне кавказскими». Автор также подвел под научное обоснование термин «таулу» (в концепте «горец»), который является единым этническим самоназванием карачаевцев и балкарцев, и аналогичен терминам «вайнах» и «адыг» $[1,17]$.

Итак, существует большой пласт серьезной литературы, в том числе и от признанных ученых, посвященных решающей роли аланских племен в формировании карачаево-балкарской народности. В 1930-1931 гг. В. И. Абаев возглавил лингвистическую экспедицию АН СССР в верховья рек Кубани, Баксана и Черека. В результате этих экспедиций ему удалось продемонстрировать осетино-балкарские лексические схождения терминами неживой и живой природы, названиями культурных растений, терминами материальной культуры, а также медицинскими, социальными, этническими, религиозными, фольклорными, мифологическими и т.д. терминами. Ученый обнаружил в языке и фольклоре осетин, балкарцев и карачаевцев обширные и разносторонние схождения, которые позволили ему заключить следующее: Осетинские элементы в балкаро-карачаевском языке не являются результатом новейшего заимствования из современной Осетии, а наследием старого алано-тюркского смешения, происходившего на территории всех ущелий, 
от Терека до верховьев Кубани [3, 275]. На лексические схождения осетинского и карачаевского языков до В.И. Абаева обратили внимание В.Ф. Миллер и М.М. Ковалевский. Эти ученые подчеркивали огромное влияние осетин на формирование балкаро-карачаевцев и даже называли последних «отатарившимися осетинами» $[3,275]$. Эти мысли о схождении карачаево-балкарского языка с осетинским продолжил и автор книги, приведя в монографии дополнительные интересные подробности. В книге немало страниц, посвященных аланскому вкладу в этногенез карачаевцев и балкарцев, подчеркивается большая этническая близость осетин-дигорцев с карачаево-балкарским народом, что отразилось на их духовной словесной культуре [1,37]. Автор иллюстрирует сказанное конкретными примерами. Он пишет, что пожилые балкарцы помнили парный и десятичный древний дигорский (аланский) счет, забытый самими осетинами $[1,51]$. Дигорский этнический массив настолько значителен в Чегемском ущелье, что по преданиям даже древнее село Думала в прошлом называлось Дюгер-Эль. Здесь же, по его мнению, сохранилась небольшая возвышенность из темного песка, «которую по сей день называют Ач-Элия-Ургъан в концепте: «Святым-Элией-Пораженный». В данном случае словоформа «ач» не что иное, как дигорское «уаце» - святой, унаследованное от христианского периода» $[1,52]$.

Следует отдать должное автору: во многих местах книги (см. сc. 6, 11, 51, 72 и др.) он акцентирует внимание читателя на следующем значительном факте истории, согласно которому в те далекие времена дигорцы могли быть одним из аланских субэтносов, на языке которых балкарцы говорили до конца XVIII в. (в другом месте - до начала XIX в.), а топонимы, гидронимы и ойкомины дигорского происхождения и по сей день нередко встречаются в ущельях Балкарии. «Возможно, - пишет далее автор, - что в формировании карачаево-балкарского народа могли сыграть определенную роль и древние кавказские этносы, о которых мало что известно исторической науке» $[1,11]$. Нам трудно говорить что-либо о влиянии других народов на карачаевцев и балкарцев, но то, что они испытали сильнейшее влияние алан-осетин, это есть факт, не требующий доказательства. Когда культурная общность народов доходит до такой высокой степени идентичности, интеграция неможет ограничиваться одними лишь языковыми заимствованиями, но распространяется на все отрасли духовной культуры формирующегося народа, что вполне логично и объективно.

Несмотря на признание огромного влияния алан на формирование карачаевцев и балкарцев как этноса, а также их версии Нартиады, Малкондуев разделяет мнение той части ученых «Которые в основном придерживались автохтонного, субстратного подхода к решению проблемы изначального возникновения и зарождения памятника «Нарты» $[1,114]$. Он отдает предпочтение тюрко-монгольским параллелям в культуре карачаевцев и балкарцев. На наш взгляд преувеличенно представлена и самобытность карачаево-балкарского нартовского эпоса за счет тюрко-монгольских влияний. Еще раз отмечаю, что ко всем этим вопросам я подхожу только как историк. Более подробный анализ книге видимо сделают специалисты-фольклористы. Однако обратимся к истории. 
Не подвергается сомнению тот факт, что каждый кавказский народ - носитель Нартиады обогатил нартовский эпос своей самобытной древней традиционной культурой, собственными фольклорными произведениями. Поэтому и мы утверждаем, что именно на базе протоэпоса родились и сформировались все национальные версии нартовских сказаний со свойственными им особенностями. В этом плане карачаевцы и балкарцы не являются исключением. Степень влияния алано-осетинского эпоса на карачаево-балкарский быт была значительной. Читатель бы обратил на это внимание, если бы наряду с параграфом об общих и сходных чертах карачаево-балкарского эпоса «Нарты» и древнетюркских эпических памятников, автор рассмотрел аналогичный параграф об общих и сходных чертах карачаево-балкарских нартовских сказаний с осетинской Нартиадой. Их явно было бы не меньше, ибо как пишет автор: «Словесность народа «таулу» имеющего глубокие древнетюркские корни, в окончательном этническом формировании которого большую роль сыграли и ираноязычные аланы (подчеркнуто нами. - A. Ч.) - это симбиоз указанных двух национальных культур при значительном сохранении элементов самобытной древнетюркской этнической словесности» $[1,68]$. Несмотря на близость ряда мотивов, и сюжетных элементов осетинского и карачаево-балкарского эпосов, влияние древнеаланской культурной словесной традиции, автор, тем не менее, подчеркивает значительное сохранение самобытной древнетюркской этнической словесности. Чтобы подтвердить сказанное Малкондуев приводит многочисленные фольклорные свидетельства из тюрко-монгольских культурных традиций. Я позволил себе проанализировать в критическом русле примеры, которые уважаемый автор приводит как привнесенные из тюркской прародины, и провести некие сравнительные параллели с точки зрения историка.

1. Со стороны тюркоязычных пращуров, карачаевцы и балкарцы находятся в наиболее близком родстве с кумыками и ногайцами. Однако у кумыков, как и у ногайцев, нартовский эпос отсутствует вообще. Вопрос: можно ли в таком случае говорить о самобытности варианта Нартиады у карачаевцев и балкарцев - единственных тюркоязычных народов Кавказа, которые к тому же, как народность сформировались на Кавказе? $[1,18]$ Здесь получается какая-то логическая неувязка.

2. Автор книги приводит легенду, согласно которой прародитель первой карачаево-балкарской общины Дебет появился на свет от священного брака Бога Неба и Богини Земли «Когда было сотворено вверху голубое небо и внизу бурая земля, между ними обоими были сотворены сыны человеческие» $[1,55]$. О рождении Дебета приводится следующая цитата:

Тейри Неба женился на Тейри Земли Загрохотало небо - зачала Земля Девять лет и девять дней она тяжелая была Потом земля разверзлась, и родился Дебет

$$
[1,56] \text {. }
$$

«После того как Тейри (бог) были сотворены небо и земля, между ними были сотворены люди» $[1,68]$. Между тем это предание далеко не оригинальное, тем более не является самобытно тюркоязычным. Миф о браке между Отцом-Небом и Матерью-Землей широко известен во всем мире и известен не только тюрко-монгольскому кругу народов. И Уархаг, дед Урузмага не является пер- 
вым нартом. Не буква в букву, но разве не точно также звучит следующий мотив из осетинского эпоса: «Родоначальник человечества носит названиеУæхтанæг». «Нарт Вахтанаг был сотворен лоном земли и дыханием неба» [4, 182-184].

3. Вряд ли можно назвать вошедшим в эпос из тюрко-монгольского сюжет о рождении карачаево-балкарских нартов от волчицы (Ерюзмек вскормлен волчицей) $[1,71]$. Похожие сюжеты представлены и в осетинской Нартиаде. Само имя одного из родоначальников нартов в осетинском эпосе Уархаг буквально означает волк (Абаев), а братья Ахсар и Ахсартаг, сыновья Уархага, соответственно были воспитаны волком $[5,306]$. Один из нартовских героев Сюруай, «подобно римским близнецам, выкармливается волками.... Сослан становится неуязвимым после того, как он выкупался в волчьем молоке» $[2,33]$. Волк играет особую роль в мифологии многих народов мира. Рем и Ромул, основатели Рима тоже были вскормлены волчицей в мифе, который возник задолго до того, как мы можем говорить о начале тюркско-монгольского периода в истории. Во всех случаях мы имеем один и тот же тотемический миф о происхождении племени от волка.

4. Согласно Малкондуеву, имя Сатаней восходит к тюркским руническим письменным памятникам VI-XII вв. к так называемой богине материнства Умай, которая характеризуется как Сатанате, т.е. мать Сатан. По его предположению термин проник на Северный Кавказ вместе с первыми тюркскими переселенцами - гуннами во II в. Это мнение имеет право на существование, хотя на наш взгляд оно, мягко говоря, малоубедительно. Ведь неизвестно сохранился ли этот термин у других тюркских на- родов, двинувшихся далее на запад. Скажем, среди них были кумыки и ногайцы, но у них, как мы обозначали выше, нартовского эпоса нет вообще. Логично было бы заключить, что если термин был известен предкам карачаевцев и балкарцев, то почему упоминание о нем не осталось у ногайцев и кумыков? Тем более границы Тюркского каганата не распространялись на Северный Кавказ [1, 50-51], т.е. на ареал, где сформировался карачаево-балкарский этнос. Данный экспонат принадлежал тувинцам, и нигде более ни в какой привязке не упоминается. Что касается аланской царевны Сатаник, то этот сюжет стоит наиболее близко к историческим реалиям, и звучит более правдоподобно, так как аланская царевна Сатаник - реальный исторический персонаж (см. Мовсес Хоренаци). Думается, армянская версия не менее значима, чем тувинский экспонат. Не ясно в этом контексте в чем же заключается самобытность сказаний о Сатаней. Все перечисленные качества, свойственные ей также подробно описаны и в осетинском эпосе. Сомнительно также предположение о возможной тюркской основе ее имени $[1,90]$. Опять-таки ссылаясь на фольклор других тюркских народов, надо полагать, что что-то подобное должно было остаться и там.

5. Также вряд ли можно назвать самобытным тюркско-монгольским явлением борьбу нартов с великанами (племя эмегенов) $[1,70]$. Один из заглавных, начальных мотивов осетинских нартовских сказаний - борьба с гумирами, уаигами-великанами Маргузом, Бибыцем, Елтоганом, Мукара и многими другими.

6. Позвольте считать натяжкой идею обособления лошади, идею того, что особое отношение к лошади было привнесено исключительно из тюркской культу- 
ры $[1,80]$. Маловероятно, чтобы все, что связано с образом боевого коня, всадника, их дружбу и неразлучность являлось религиозно-мифологическим наследием, имеющим только лишь древнетюркскую основу $[1,27]$. Всеми этими качествами и особенностями с лихвой переполнены сюжеты всех версии Нартиады, в том числе осетинские сказания. Конь в нартовском эпосе осетин занимает исключительно высокое положение, о чем свидетельствует хотя бы имена лошадей, встречающиеся в сказаниях. Кроме общего названия лошади в осетинском эпосе, которое тоже не ограничивается одними лишь терминами - бжх, жрфбен, хайуан, сефсургъ. В осетинской Нартиаде встречаются и их имена: Аласа, Алыпп, Кокцаул, Арахъан, Чесана, Хор-хор, Араппаг, Ресе, Алузджаз, Саулох [4, 132-144]. Вряд ли без особого пиетета к лошади можно было бы говорить о таком разнообразии именно имен, а не кличек.

7. Трудно отнести к самобытному явлению и сюжеты карачаево-балкарской Нартиады о «Первом нарте Дебете» (осет. Курдалагон), о великанах-эмегенах, о том, как появились нарты. И в осетинском эпосе начало нартов связано с первым человеком, родившимся из небесного огня. Согласно космогоническим мифам осетин, в числе первых на земле появились нарты. До них мир был спящим, беззвучным и темным. Позже на небе появилось колесо солнце, пламя луны, мерцание звезд, заря и от горизонта к горизонту протянулся млечный путь. Затем от их света зажглось синее пламя, и с неба упала искра огня, превратившаяся в черную золу. Из этого пепла Бог сотворил нартов $[6,477 ; 7$, 116-117]. Согласно «Начальному сказанию» в начальный период возникновения жизни, после появления велика- нов, Донбеттыров, далимонов, гумиров, между небом и землей появилось пылающее огнем существо, которое оттуда бросилось в море и там закалилось. Так появился на свет Бжстыскерытых, покровитель огня, первый Бог, первый демиург, и его потомство - нарты, народ, рожденный от пламени огня и закаленный водой. Потомство Бжстыскрытых отличалось силой и мужеством. По некоторым вариантам сказаний первонарт Сауасса произошел от Бжстыскерытых. От одного из его сыновей по имени Дзылау произошел род Алагата, от второго - Болатбжрзжй - Ахскртхегатке, а от третьего сына Бола - Болат-Курд родились сыновья Уахтанаг и Уархаг [8, 25-26; 9, 173-175].

8. Сомнительно и то, что «в памяти балкарских певцов-сказителей пучше, чем у всех остальных носителей Нартиады, сохранились музыкально-песенное и стихотворно-поэтическое исполнение» $[1,24]$. Думается, такое заключение позволительно делать лишь после сопоставительного анализа всех версий нартовских сказаний.

9. Весьма неубедительны также объяснения терминов Хыз и, особенно Гур из тюркских этнонимов $[1,56]$. Ведь имело же место историческое событие - взятие осетинским царевичем Багатаром в XIV в. грузинской крепости Гур $[10,56]$. Именно так осетины до сих пор называют г. Гори в Грузии.

10. Из четырех циклов представленного эпоса лишь цикл о первонарте Дебете (двойник осетинского Курдалагона) его сыне Алаугане и внуке Карашауайе является оригинальным, чего нельзя сказать о цикле Сосруко и, особенно, Ерюзмека и Сатаней. Последний цикл, видимо, все же заимствован из осетинского эпоса. Об этом свидетель- 
ствует хотя бы следующее: сказаний этого цикла в карачаево-балкарском эпосе насчитывается всего 29, тогда как в осетинском с вариантами сказания о Уырызмаге и Сатане перевалили за 140 сказаний. Потому утверждение Ю.С. Гаглойти о том, что карачаево-балкарский эпос в основе заимствован из осетинского, следовало опровергать не голословно, а конкретными примерами [1, 26-27].

11. Полагаю, что специальная глава, посвященная параллелям с калмыцким эпосом «Джангар» не совсем укладывается в основную тему монографии. Ведь и у калмыков не было нартовского эпоса. Скорее всего, эти параллели проводятся для того, чтобы подтвердить постулат автора о самобытности карачаево-балкарского эпоса.

12. На наш взгляд, нет достаточных оснований говорить об обособленной самобытности балкаро-карачаевской версии эпоса по сравнению с другими вариациями Нартиады. Известно, что из всех тюркоязычных народов нартовский эпос существует только у карачаевцев и балкарцев, к тому же у народа, сформировавшегося на Северном Кавказе. У других народов большой тюркоязычной семьи его нет. Повторюсь, но нет эпоса и у близкородственных карачаево-балкарцам, и, кстати, сформировавшихся также на Северном Кавказе, кумыков Дагестана. Получается, что только у далеких предков будущих карачаевцев и балкарцев зародились самобытные элементы нартовских сказаний. Но в истории так не бывает, и историкам это хорошо известно.

Далее. Не слишком ли явными являются осетино-, а если точнее, то дигоро-карачаево-балкарские нартовские параллели, их поразительная сюжетная схожесть? В подтверждение своей мысли автор приводит сказание о Болат-Хамыце, впервые записанное в 1901 г М. Гарданти в Дигории и повторно записанное в Чегемском ущелье от балкарского сказителя уже в 1981 г. Однако, это сказание не является исключительным. К примеру, Малкондуев находит много общего в образах Сатаней и Сатана, что соответствует действительности. Для иллюстрации сказанного приведу всего один штрих. В осетинском эпосе о Сатане сказано: «цвет ее лица был подобен солнцам и лунам», «не в одно, а в сто солнц и лун сияла красота Сатаны». В карачаево-балкарском: «Одна сторона лица сияла, как луна, а другая как солнце». Еще большую схожесть можно найти в сказании «Как Урузмаг разводился с Сатаной», Урузмаг предложил ей в гневе вернуться в родительский дом, взяв с собой, что только пожелает. На прощальном пире Урузмаг выпил и опьянел, а когда отрезвел, он обнаружил себя в повозке, в пути. Рядом сидела Сатана, и он спросил ее: «Куда мы едем?». На это Сатана ответила:

- Ты, наверное, забыл, что прогнал меня из дому. Вот я и направляюсь в родительский дом.

- Ладно, - сказал Урузмаг, - но объясни мне, зачем ты меня с собой взяла?

- Вчера отсылая меня в родительский дом, ты сказал: «Забирай с собой любые сокровища, которые тебе по душе!» А для меня нет ничего дороже и любимей тебя, вот я и взяла тебя с собой, а все остальные сокровища оставила дома $[11,38]$. В карачаево-балкарском варианте сюжет повторяется один в один: Ерюзмек в гневе предлагает жене взять в доме самое ценное и покинуть его двор. Просыпается богатырь в степи в повозке Сатаней, и на вопрос Ерюзмека: «Почему я здесь?» - она отвечает: «Я забрала по твоему совету из дома самое ценное для 
меня» $[1,28]$. Подобных примеров можно привести много. Так, по сути своей карчаево-балкарский танец-песня Чоппа мало чем отличается от осетинского Цоппай. В то же время этноним авар в форме ауар сохранился только в балкарском и осетинском языках $[1,52]$.

13. В своей работе Малкондуев, противопоставляя дигорское с иронским, постоянно пользуется словосочетаниями: «Дигорский нартский эпос», «дигорский язык» (см. стр. 63 и др.). Между тем, никакого отдельного дигорского эпоса нет, а имеются осетинские нартовские сказания и осетинский язык с его двумя диалектами.

Нет четкого представления у автора и о циклах нартовских сказаний карачаевцев и балкарцев. К примеру, на стр. 25 автор говорит о 12 циклах нартовских сказаний. На стр. 28-29 он отмечает четыре цикла эпоса. На стр. 38, автор характеризует осетино-карачаево-балкарские фольклорные связи «на примере цикла о Болат-Хымыце» $[1,38]$. Говоря о близости карачаево-балкарского эпоса с кабардинским, Х. Х. Малкондуев договаривается об этническом родстве балкарцев и кабардинцев, у которых будто бы были общие предки - хазары. Между тем, участие хазар в этногенезе кабардинцев довольно спорно. Как они могли иметь общих предков, когда кабардинцы относились к народам - представителям кавказской языковой семьи, тогда как хазары были тюркоязычными?

14. Исследуя сказание о рождении Ерюзмека, записанное в Чегемском ущелье, где было сильно дигорское влияние, автор не исключает возможность того, что сказание это принадлежит, в равной степени, как «субэтническим таулу-чегемцам, так и субэтническим осетинам-дигорцам» [1,103]. Думается, при идентичном содержании сказаний нельзя говорит о равной принадлежности их обоим этносам. Один из них заимствовал у другого, потому что оба народа никак не могли быть одновременно субэтническими.

15. По многим своим параметрам и характеристикам Нартиада осетин превосходит аналогичные вариации. Это признал и М.Джуртубаев, которого в явном пристрастии к осетинскому эпосу не заподозришь. Говоря об осетинском нартовском эпосе, он подчеркивал: «Сильное впечатление производят и его художественные достоинства, богатство сюжетов, обилие антропонимов, этнонимов и топонимов как, разумеется, и объем накопленного к тому времени материала». К примеру, если исследователю С.-А. Урусбиеву тогда удалось записать 29 сказаний, то, как отмечено нартоведом Т.А. Хамицаевой, в дореволюционный период рассказали или напели осетинские нартовские сказания 28 сказителей, в репертуаре которых число сказаний колеблется от одного до 15, что в среднем составляет более 200 сказаний $[12,137]$. Богатство осетинского эпоса подчеркивали Дж. Шанаев, В. Пфаф и др. Поэтому полагаем, что позиция, когда причиной относительной бедности других версии называют якобы тот факт, что их вовремя некому было собирать, не совсем верна. Малкондуев пишет, что лишь в 60-70-х гг. $\mathrm{XX}$ в. исследователи Карачая и Балкарии приступили к сбору своего эпоса. Между тем, с конца 90-х гг. XIX в. после обнаружения их С-А. Урусбиевым до незаконной депортации карачаевцев и балкарцев прошло как минимум полстолетия, когда никто никому не мешал собирать свой фольклор.

16. Неверно и утверждение, что В. Ф. Миллер и Ж. Дюмезиль были зна- 
комы с одной только осетинской национальной версией, которая и сформировала у них мнение в пользу возникновения эпоса в осетинской этнической среде [1, 51]. Кроме статьи «Черты старины в сказаниях и быте осетин» все суждения Миллера о Нартиаде носят общекавказский характер. Что касается Ж. Дюмезиля, то основные его труды о нартах «Легенды о нартах», «Книга о героях» и «Миф и эпопея» написаны на основе анализа всех национальных версии Нартиады. Не будем забывать и о том, что он был специалистом по языкам и фольклору кавказоязычных народов, прежде всего убыхов, которыми занимался особо, и лишь позже заинтересовался осетинскими сказаниями.

17. Следует отдать должное автору. Он постоянно подчеркивает множество явных параллелей не только в описании богатырей, но в их образе жизни и подвигах, в окружающем художественно-предметном мире, композиционном построении двух эпосов (осетинского и карачаево-балкарского), объясняя это тем, что общность эта традиционно берет начало из глубокой этнической древности этих народов $[1,17]$. Отмечается весомая роль скифов и алан в формировании карачаево-балкарского народа $[1,114]$. Так в чем же эта роль? Согласно логике вещей, когда определенный этнос говорит на языке другого этноса, то в равной мере он воспринимает и его духовную культуру, в том числе и фольклорные памятники. Аналогичная ситуация произошла с тюркоязычными болгарами, которые от Поволжья продвинувшись до юго-восточной Европы смешались со славянами и, хотя сохранили свое этническое имя, но восприняли славянский язык и, вместе с тем, культуру народа, в среде которого растворились.
18. Автор считает, что при всей близости к текстам кавказской Нартиады, карачаево-балкарский богатырский эпос остается национальным, самобытным творением этого народа. То, что эпос обладает всеми свойствами национального творения, - нет сомнения. Сомнения вызывают лишь претензии на самобытность. Кроме всех вышеуказанных причин стоит отметить тот факт, что на протяжении долгого времени эти народы говорили на дигорском диалекте осетинского языка, что не могло не повлиять на их духовную культуру. Автор, противореча себе, многократно подчеркивает большое влияние скифо-алан на формирование карачаево-балкарской народности и говорит о значительных эпических параллелях и заимствованиях. Получается что-то нелогичное: этническую основу карачаево-балкарской народности создал симбиоз аланских и тюркских племен, а основа национального эпоса - тюрко-монгольская.

Вопреки логике, ученый отдает приоритет привнесенным тюрко-монгольским мотивам: «Ни время, ни пространство не смогли стереть из генетической памяти близких по происхождению, языку и духовной культуре тюркско-монгольских народов множества общих черт, проявляющихся в различных жанрах фольклора, начиная с магической поэзии до богатырского жанра». И, резюмируя изложенное в книге, говорит о «наличии десятков мотивов, отсутствующих в других национальных версиях» $[1,117]$. К сожалению, привлеченный в книге материал, не позволяет делать подобное заключение.

Автор разделяет вывод А. 3. Холаева, который заключает, что «Карачаево-балкарская версия нартского эпоса является самобытным и оригинальным творением этих народов. Связанный с обще- 
кавказской эпической традицией, эпос о нартах вместе с тем впитал в себя и эстетический опыт балкарцев и карачаевцев, аккумулированный в различных жанpax фольклора. В карачаево-балкарских сказаниях о нартах отразились история этих народов, их философия, мировоззрение, особенности психологии, быт и нравы» $[1,110]$. Автор книги солидарен с Холаевым, он заключает: «При всей близости к текстам кавказской Нартиады карачаево-балкарский богатырский эпос остается национальным, самобытным творением». По большому счету, эта претензия на существование еще одного центра формирования нартовских сказаний на Северном Кавказе. Получается, у карачаевцев и балкарцев существовал свой собственный центр формирования эпоса. Однако, материал, привлеченный выше, никак не позволяет делать подобное заключение.

19. Автор считает сомнительными выводы В.И. Абаева, когда тот пользуется слитным употреблением термина «тюрко-монгольское». Малкондуев поправляет его и пишет, что «при всей близости тюркских и монгольских этносов, у них не было общего этнического памятника, т.е. богатырского эпоса, если тюрки появились на юге современной России в III-IV вв. н.э., то монгольская конница впервые вступает сюда лишь в XIII в.» [1, 54]. Между тем, указывая В. Абаеву, сам $\mathrm{X}$. Малкондуев охотно пользуется указанным выше слитным словосочетанием.

20. Гибель нартов - общий финал всех версий Нартиады. Автор соглашается с Т. М. Хаджиевой, отмечая, что «...из кавказских народов - носителей эпоса «Нарты» только в карачаево-балкарской версии бессмертны главные персонажи произведения», и ссылается при этом на традиционные тюркско-монгольские сюжеты эпических сказаний $[1,36]$. Этот общий тезис Малкондуев иллюстрирует бессмертием Сосруко. Малкондуев считает, что бессмертие Сосруко может считаться доказательством самобытности карачаево-балкарского эпоса. Но ведь и в осетинской версии не говорится, скажем, о смерти Сатаны. Можно ли это считать выражением самобытности осетинской версии?

21. Не будем касаться хронологических и географических нестыковок в тексте, касающихся, скажем, времени пребывания гуннов на Северном Кавказе, или границ Тюркского каганата. Автор считает неубедительным мнение всемирно признанного специалиста по древней истории Северного Кавказ В. А. Кузнецова о скифо-аланском ядре эпоса. Здесь также хотелось бы услышать аргументированные доводы против, а никак не голословные возражения.

22. Как видно из вышеизложенного, общие мотивы о схожести осетинского и балкаро-карачаевского эпосов превалируют над самобытностью, якобы привнесенной из тюркской прародины. Но как же тогда получается, что карачаево-балкарцы сложились как народность после татаро-монгольского нашествия на Аланию, на территории бывшей Западной Алании? Между тем к указанному времени нартовский эпос прошел уже тысячелетний период своего развития и к концу этих исторических потрясений был сформирован. Это мнение разделяют все признанные специалисты Нартиады.

Думаю, что озвученных вопросов более чем достаточно, но они несущественно влияют на общее приятное впечатление от монографии в целом. Книга реально демонстрирует, сколько на самом деле у нас общего. И при этом мы как народы умудряемся сохранять нашу 
индивидуальность. Не вижу ничего зазорного в том, чтобы отмечать те моменты в культуре, которые мы, осетины заимствовали у других народов, не приписывая им некую уникальность. Согласно Абаеву, образ Афсати проник в осетинский эпос из кавказского субстрата, впрочем, как и цикл Даредзановских сказаний, который пришел к осетинам из Грузии $[13,32]$. Однако эти образы и сказания настолько органично вплелись в осетинский фольклор, что мы имеем полное право заявлять в случае с Даредзантæ об осетинском эпическом цикле и об Афсати как одном из главных образов осетинской Нартиады. Говорит ли это о том, что мы должны отрицать их первооснову и при этом подчеркивать их самобытность? Конечно, нет, если мы хотим заниматься именно историей, а не околоисторическими фантазиями.

В заключении хотел бы поделиться еще одним любопытным наблюдением.
Мне приходилось держать в руках разные издания, в которых ученые из соседних, дружественных Осетии республик, исследовали различные аспекты своих версий Нартиады. Были и научно-популярные фильмы, например, об абхазской Нартиаде. Я обратил внимание на художественное оформление этих изданий, фильмов и заметил, что авторы или редакторы довольно часто используют иллюстрации осетинского художника Махарбека Туганова, правда, нигде не приводя ни указаний, ни ссылок на его работы. Не думаю, чтобы осетины особо возражали против этого. Хотя бы потому, что на фоне того, что у ученых и исследователей Нартиады всегда будут разногласия по тем или иным аспектам, великий осетинский художник Махарбек Туганов будет выступать фактором объединения кавказцев вокруг одной из мировых мифологических жемчужин, памятника мировой культуры - Нартиады.

1. Малкондуев Х.Х. Карачаево-балкарский нартский эпос. Теория. Историзм. Самобытность. Нальчик, 2017.

2. Абаев В. И. Нартовский эпос // Известия СОНИИ. 1945. Т. 10. Вып. 1.

3. Абаев В. И. Осетинский язык и фольклор. М.-Л., 1949.

4. Дзищиойты Ю. А. Вопросы осетинской филологии. Цхинвал, 2017.

5. Абаев В. И. Избранные труды. Владикавказ, 1990.

6. Осетины/Отв. ред. З. Б. Цаллагова, Л. А. Чибиров. М., 2012.

7. Чибиров Л.А. Осетинская Нартиада. Мифологические истоки и ареальные связи. Владикавказ, 2016.

8. Нартовские сказания в 7-ми томах. Дзауджикау, 2003. Т. 1. 592 с. (на осет. яз.)

9. Туганов М. С. Новое в нартовском эпосе // Известия Юго-Осетинского НИИ. 1946. Вып.1. С. 170-187.

10. Гаглойты Ю.С. Алано-Георгика: сведения грузинских источников об Осетии и осетинах. Владикавказ, 2007.

11. Нарты. Осетинский героический эпос в 3-х кн. М., 1989. Кн. 2.

12. Нарты. Осетинский героический эпос в 3-х кн. М, 1991. Кн. 3.

13. В. И. Абаев. Проблемы нартского эпоса // Нартский эпос. Материалы совещания 19-20 октября 1956 г. Орджоникидзе, 1957. С. 22-36. 